Review Article

\title{
Rivers in the Himalaya: Responses to Neotectonics and Past Climate
}

\author{
PRADEEP SRIVASTAVA ${ }^{1, *}$, YOGESH RAY ${ }^{2}$, BINITA PHARTIYAL ${ }^{3}$ and Y P SUNDRIYAL ${ }^{3}$ \\ ${ }^{1}$ Wadia Institute of Himalayan Geology, 33 GMs Road, Dehradun 248 001, India \\ ${ }^{2}$ National Centre for Antarctic and Ocean Research, Vasco-da-Gama, Goa 403 804, India \\ ${ }^{3}$ Birbal Sahni Institute of Paleobotany, University Road, Lucknow 22 6007, India \\ ${ }^{4}$ Dept. of Geology, HNB Garhwal University, Srinagar 246 174, India
}

(Received on 12 April 2016; Accepted on 30 April 2016)

\begin{abstract}
Rivers in Himalaya respond to tectonics and climate of the region on different spatio-temporal scales. Here we present a brief account of Indian contribution, on the study pertaining to the fluvial record from Himalaya during 2011-2015. Total number of papers published in SCI journals and edited books are 64 where authors have mainly focused on the understanding of (i) extreme events and their terrain responses in Himalaya (ii) records of river aggradation-incision and the forcing factors (iii) geomorphic indicators of neotectonic deformation. Emphasis has also been made towards understanding the development of frontal belt of the Himalaya, sediment production, storage and delivery in the wedge.
\end{abstract}

Keywords: Himalaya; Climate; Neotectonics and River Geomorphology

\section{Introduction}

Himalaya is a continental scale geomorphic expression of thrust and fold belt tectonics that initiated with the subduction and subsequent collision of Indian plate to Tibet. The process of orogeny involve forces that range from deep mantle to surface-atmosphere interaction. Results of Global Positioning System kinematics indicate that the processes of crustal deformation and mountain building in Himalaya and the adjoining areas is still active and have been varying during the recent past (Jade et al., 2007). Likewise, the climate, a proxy of atmospheric processes have been significantly varying during the past effecting surface processes, river erosion, transportation, aggradation and readjustments of isostatic stresses and related deformation at different temporal and spatial scale (Ray and Srivastava, 2010; Juyal et al., 2010; Theide et al., 2004). Thusclimate and tectonic stresses in Himalaya trigger extreme events, like earthquakes, landslides, cloud bursts, Glacial lakes outburst floods (GLOFs) and Landslide lake outburst floods (LLOFs). The fluvial landscape in the Himalaya, archive the signatures of these events in form of their (i) Channel gradient, pattern (ii) terraces

\footnotetext{
*Author for Correspondence: E-mail: pradeep@wihg.res.in
}

(iii) river valley filling due to damming via landslides and surging glaciers.

During the last five years (2011-2015) Indian contributions, that we summarize here, mainly focused on (i) understanding the terrain response to extreme events (ii) responses to varying climate and tectonics on the landscape (iii) neotectonic growth of the mountain front (iv) sediment dispersal and storage. The study utilized new tools of tectonic geomorphology, classical sedimentology, high resolution terrain mapping, biological (pollen and phytoliths etc.) and abiological proxies (inorganic geochemistry, magnetic susceptibility and stable and non-conventional isotopes). The bulk of the chronological framework relied upon Optically Stimulated Luminescence (OSL) dating technique with few AMS radiocarbon ages.

\section{Geology and Climate}

The accretion of the Himalaya started from the suturing of two plates at $\sim 54 \mathrm{Ma}$ along the Indus suture Zone (ISZ) and first thrusting event along the Main Central thrust (MCT) at 23 Ma. Between the two events sedimentation took place in a forearc basin 
setting in north, preserved as Indus molasses in Ladakh. This was proceeded by sedimentation in a foreland setting in Siwalik basin in the front. The Indus molasses got thrusted over Ladakh batholith along a north vergent thrust often termed as the Indus Thrust or Upshi-Baso thrust at $\sim 10 \mathrm{Ma}$ (Brookfield et al., 1984). The basal rocks of Indus molasses are marine sedimentaries and are succeeded by fluvial sedimentation towards the upper part. The geology of ISZ also comprises obducted crustal rocks and ophiolitic melanges. In the south of ISZ, separated by north vergent Zanskar Counter Thrust, lies $\sim 10 \mathrm{~km}$ thick, Palaeozoic-Mesozoic, un-metamorphosed Tethyan sedimentaries. The Tethyan Himalaya deformed under extensional tectonic regime and shows presence of crystalline domes (like leo-pargil dome). Towards the south lies the Higher Himalayan crystallines (HHCs) which is bounded by South Tibetan Detachment system (STDS) in the north and the Main Central Thrust (MCT) in the south. Metasediments of Lesser Himalaya lie between the MCT and the south vergent Main Boundary Thrust (MBT). The lesser Himalayan rocks are thrusted over the deformed fluviatile Siwalik foreland basin sequence along the MBT that in turn are thrusted over the modern Ganga Alluvium along the Himalayan frontal Thrust (HFT) (Valdiya, 1980).

Geomorphologically, cross section profile of Himalaya shows marked variations in elevation ranging from $\sim 400 \mathrm{~m}$ at the mountain front to around $1000 \mathrm{~m}$ Siwalik hills to $\sim 1200 \mathrm{~m} \mathrm{LH}$ and $>3000 \mathrm{~m}$ Higher Himalaya. The orography of these ranges pick up at two places first in the south between HFT and MBT and then second above MCT (Bookhagen and Burbank 2010). These orographic breaks make two belts of focused precipitation in Himalaya that extend longitudinally from Kashmir Himalaya in the west and Arunachal Himalaya in the East. Although, the intensity of precipitation does changes markedly from west to east and shows an increasing trend from $\sim 1500 \mathrm{~mm} / \mathrm{a}$ in the west to $>3000 \mathrm{~mm} / \mathrm{a}$ in the east. Likewise a decreasing rainfall trend exists from south to north; e.g. southern front of Garhwal Himalaya receives $\sim 2200 \mathrm{~mm} / \mathrm{a}$ whereas the Ladakh in north, that lies in rain shadow of Himalaya, gets only 300 $\mathrm{mm} / \mathrm{a}$ of precipitation. Based on the structural configuration and climate Himalayan rivers can be broadly classified into two classes. (i) Arid NW and Ladakh Himalayan rivers that drain through the drier climatic regime, flows parallel to ISZ. These rivers are largely fed by the glacial melt and westerlies e.g. the Indus and the Spiti. (ii) Rivers draining southern front of Himalaya and cutting major structural discontinuities such as the STDS, MCT, MBT and HFT orthogonally e.g. the Sutlej, the Bhagirathi, the Alaknanda, and the Brahmaputra etc. The hydrology of these rivers is sustained by a combination of glacial melt and the precipitation contributed by the ISM and

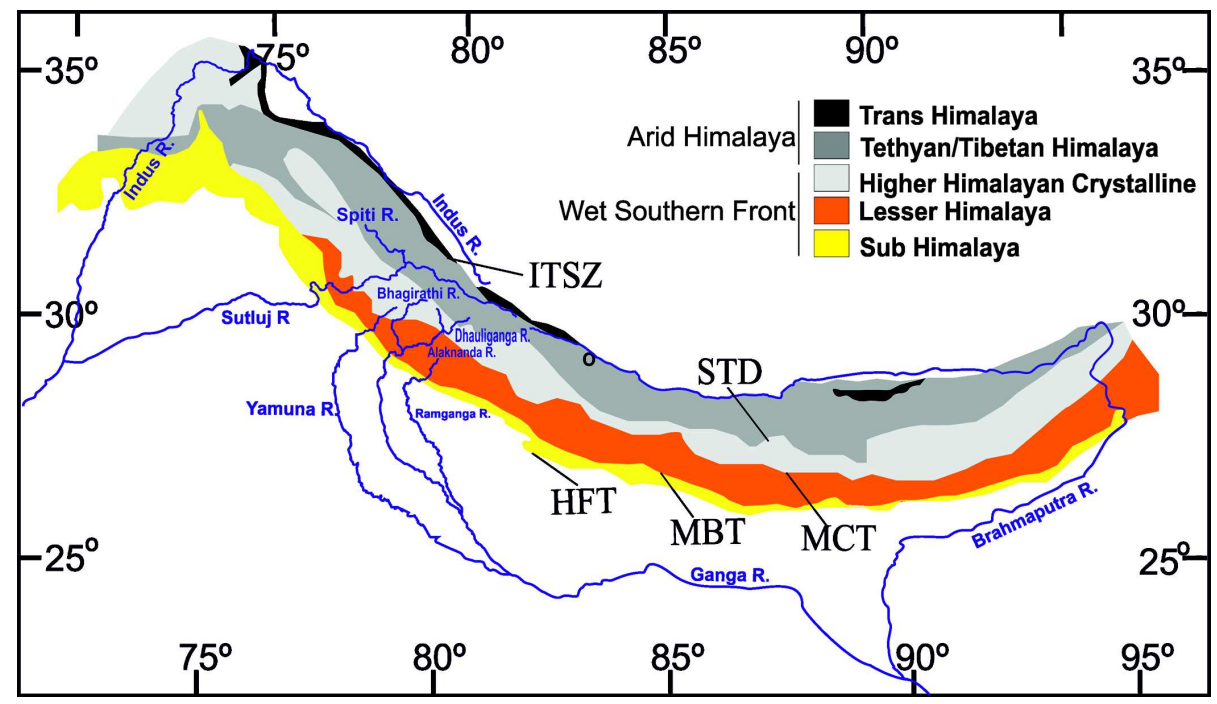

Fig. 1: Geological map of Himalaya showing major rivers and litho-tectonic discontinuities (Gansser, 1964). (i) Indus Tsangpo Suture Zone (ITSZ), (ii) South Tibetan Detachment (STD), (iii) Main Central Thrust (MCT), (iv) Main Boundary Thrust (MBT), (v) Himalayan Frontal Thrust (HFT) 
the mid-latitude westerlies. However, those rivers which have their headwaters in the Lesser Himalaya and Siwalik are dominantly fed by the ISM. Fig. 1 shows the geology and major rivers of Himalaya.

\section{Terrain Response to Extreme Climatic Events}

Besides several occurrences of cloud bursts and landslides, the last half decade or so in Himalaya will be known for two major devastating floods (i) August 2010 floods in Leh, Ladakh and (ii) June 2013 floods in UttarakhandHimalaya. During 4-6 August 2010 a large part of Leh and Ladakh was affected by series of cloud bursts and flash floods when $>9000$ people were affected and $\sim 255$ were reported dead and 71 settlements were damaged. The cloud bursts occurred in the headwater region of southerly draining tributaries of Indus River of Choglamsar, Saboo and Phyangnalas (streams). The modelled hydrograph, based on field observations indicated that in these nalas the flood magnitudes were more than an order of magnitude high than the base flows (Thayyen et al., 2013). Pre and Post event analysis of satellite data of flood effected area indicated that as result of mudslides, mudflows channels broke into their flood plains and the width of streams got widened by $>25$ times (average width of the flooded channels is $\sim 25$ $\mathrm{m})$. The dense population and civil structures on the flood plains increased the flood vulnerability in the area (Juyal, 2010; Bhatt et al., 2011). The year 2010 was a high rainfall year for the Induscatchment as a whole and the perspective from middle and lower reaches of the river via remotely sensed data indicated that the riverbed of the channel, due to increased sediment load, has been aggrading during the last few decades. This caused an increase in the cross-valley gradients with concomitant increase in flood inundation (Gaurav et al., 2011).A trend analysis of rainfall time series (1979-2013) indicated that the terrain experienced 34 extreme rainfall events for which the upper atmospheric interactions between southward advancing extratropical circulations and moisture laden tropical monsoon circulations is implicated (Vellore et al., 2015).

During 2013, monsoon, in Uttrakhand Himalaya, arrived early and generated a heavy spell of rainfall between 14-18 June. Weather observatory of Wadia Institute of Himalayan Geology, located near Chorabari glacier (in the headwaters of Mandakini river) indicated $>300 \mathrm{~mm}$ rainfall in $24 \mathrm{hrs}$ (Dobhal et al., 2013; Singh, 2013; Sati and Gahlaut, 2013) and satellite data analysis suggested $\sim 600 \mathrm{~mm}$ of rainfall in $36 \mathrm{hrs}$. This excess rainfall and snow melt contributed heavily to the discharge of river causing massive flood, bank erosion and landslides in the region. As a result of this flood $\sim 4000$ people lost their lives and $\sim 12000$ crore of rupees of property was lost in the state of Uttarakhandand the magnitude, both in terms of hydromorphology and vulnerability, of this flood was highest as compared to past such experiences from years 1893, 1894 and 1970 (Rana et al., 2013; Ziegler et al., 2014).The post flood geomorphic studies along the rivers Mandakini and Alaknanda indicated that this flood caused massive aggradation of the riverbed where the sediment was mainly sourced from moraines and fans located in trans-Himalayan region and large landslides in Higher and Lesser Himalaya. The study also highlighted the bulking of river at places was caused due to the erosion of the power project generated muck (Sundriyal et al., 2015). An interesting study using geomorphic parameters like river long profile and steepness index suggested that the loci and pattern of damages during the extreme events are predictable and that the areas with rapid erosion are highly sensitive to extreme events (Devrani et al., 2015). Similarly, using hypsometric integral (HI) and valley floor width to valley height ratio $\left(\mathrm{V}_{\mathrm{f}}\right)$ factor along the Alaknanda River, it is suggested that zones in the vicinity of Munsiari and Ramgarh Thrust (MCT zone) and North Almora Thrust are more susceptible to landslides and damages during such extreme events (Shukla et al., 2014). Utilizing morphometric analysis in the headwaters of Pinder River, Bali et al (2012) suggested that watersheds with higher form factor are more prone to flash floods.

A study considering a thermodynamical features of 2013 rainfall event suggests that this was a result of interaction between westerly tropospheric trough and lower tropospheric southeasterly monsoon in association with monsoon related low pressure system developed over north India (Kotal et al., 2014). This rare combination of atmosphere and orographic interaction in Himalaya caused widespread excess rainfall. The paleoflood record from Alaknanda river valley indicates that 25 large floods occurred during the last 1000 years, with an average recurrence interval of 40 years. This flood frequency increased (flood 
interval of 21 years) during the Medieval Climate Anomaly and decreased significantly during the Little Ice Age (interval of 63 years) (Wasson et al., 2013). This work also indicated that most of the large flood involve activities like GLOFs or LLOFs.

The extreme rainfall events in Himalaya are known to induce large-scale slope destabilization (landslides). In the years 2010 excess rainfall activity in Garhwal Himalaya and adjoining areas caused widespread slope failure activity. A study conducted along the Alaknanda River on Rishikesh-Mana Highway reported occurrence of $\sim 300$ landslides during August-September of 2010 and where the majority of them clustered around the MCT, Alaknanda Fault and Saknidhar Thrust (Sati et al., 2011). Similar events were reported from Ukhimath and Asi Ganga Valley to have occurred during monsoon rains of year 2012, where 3 days of incessant rains caused massive landslides and debris flow (Islam et al., 2014; Gupta et al., 2013; Rana et al., 2012).

\section{Fluvial Response to Climate-Tectonic Coupling:}

River catchments respond sensitively to tectonic and climatic perturbations at time scales varying from decadal to multi-millennial time scale. Stream power of a channel is a form of net available energy that it utilizes to erode, transport and deposit its sediment load. The increase in stream power can be imparted via one or combination of factors like increased gradient, decreased sediment load, increased water budget and vice-versa. The surplus stream power is utilized in incising the bedrock or laterally cutting/ bevelling the valley walls and increased its sinuosity of the channel. In Himalaya these factors can be modified by uplift and/or increased precipitation and sediment load and therefore the river systems operating in different climate-tectonic domains of Himalaya respond differently under similar magnitude/ threshold perturbation. Geomorphological evolution of rivers has largely responded to phases of climatetectonic evolution of Himalaya and demonstrate a geomorphic hierarchy (Ghosh et al., 2015). During the last five years, the focus has been towards understanding river responses in drier Himalaya and southern front. In drier Himalaya, mainly the Indus, the Tangtse and the Spiti, whereas in the southern front rivers like Alaknanda-Ganga; the Kosi were studied.

\section{Arid NW and Ladakh Himalaya}

The arid part of Himalaya receives large part its moisture from westerlies and remains dry during most part of the year. However, in the excess monsoon years, ISM related rainfall also makes significant contribution and cause flooding. The Indus, the Tantse and the Spiti river, where the Indus flows along the ISZ, the Tangtse valley is affected by Karakoram strike-slip fault and the Spiti river responds to extensional regime of tectonic unit located between the STDS and ZCT (Zanskar counter thrust). Thus the landscape of arid Himalaya, Ladakh, in particular, provides an opportunity to understand evolution of Himalaya under hydrologically stressed fluvial environment (Juyal, 2014). The Indus River flows from East-west from Nyoma where the gradients are gentler then makes deep and narrow gorge uptoUpshi from where it opens up into a wide valley of Leh. From Leh downstream it cuts through Indus molasses and makes deepest gorge in the NW Himalayan Syntaxes region and finally drains into foreland. Sant et al. $(2011 \mathrm{a}, \mathrm{b})$ provided a synoptic view on the morphostratigraphy of the Leh valley and identified glacio-fluvial, aeolian and lacustrine processes as primary agents in evolving the landscape.

Indus River, along its course, preserves phases of valley filling, formation of lakes due to damming of Indus by moraines, large fans and landslides and aeolian aggradation. The bulk radiocarbon and AMS ages along with few luminescence chronologies of paleolake sequences indicate their formation during the post Last Glacial Maximum (LGM) and during Early Holocenewarmer climatic phases (Phartiyal et al., 2013). Developing on this, Nag and Phartiyal (2015) suggested presence of three megalakes in the Indus valley (i) Lamayuru paleoloake spanning from $35-26 \mathrm{ka}$; (ii) Rizong paleoloake from 17-13 ka and (iii) Khaltse-Saspol paleolake from 14-5 ka. The authors attributed seismicity, landslide and other mass movement activities responsible for the damming of the Indus and formation of these lakes in the past. Past records of such lake outbursts in and around Leh valley are reported as well (Sangode et al., 2011; 2013).

The landscape of Tangtse River, in TransHimalayan region, is largely affected by the strikeslip Karakoram fault. The $50 \mathrm{ka}$ records from this 
river revealed the presence of sixth small basin of Pangong Tso that at present has five basins (Phartiyal et al., 2015). The presence of this sixth basin was dated between 10-5 ka. Further, the record indicated a phase of active fluvial aggradation at $\sim 48 \mathrm{ka}$ and 30-21 ka and valley incision took place between 22$10 \mathrm{ka}$ (Phartiyal et al., 2015). Likewise, the Spiti river that flows through the Tethyan Himalaya showed massive aggradation between 50-30 ka and 14-8 ka and the landscape also showed evidences of extension during the Holocene (Srivastava et al., 2013a). Geomorphic indicators like Basin Asymmetry, topographic symmetric factor, Stream length gradient index, Hydraulic and topographic sinuosity indices in the Spiti river basin also indicated neotectonic deformation under active extension in KaurickChango fault (Phartiyal and Kothyari, 2012)

\section{Wet Southern front of the Himalaya}

\section{Kumaun-Garhwal Himalaya}

Southern front of Himalaya that receives full impact of monsoon and is traversed by several south verging continental scale thrust (MCT, NAT, MBT, HFT etc) and local faults (e.g. Alaknanda fault). The Ganga River is the principle river of this region with River Tons being the longest stem (Verma et al., 2014). The region around MCT experiences several earthquakes of small medium magnitude that induce hundreds of landslides in the vicinity of this thrust and several other thrusts as well (Saha et al., 2002). There are ample evidences indicating landslide activity being linked to neotectonic and ongoing deformation along the MBT as well (Kothyari et al., 2012). Thus the combination of factors, like high rainfall, earthquakes, landslides and riverine erosions makes the landscape of this region quite sensitive event at century time scales (Pathak et al., 2013). Devrani and Singh (2013) documented measurable changes in the landscape around Srinagar (Garhwal) since $\sim 1729$ where not only processes like mass wasting, the fill terraces of rivers also erode and add significantly to the sediment load of the active channel (Singh et al., 2012). Similarly, on the longer time scales there are evidences of increased erosion and sediment supply leading to rapid aggradation in river valleys, formation of fossil valleys and epigenetic gorges as documented from Alaknanda River valley between 15-8 ka (Chaudhary et al., 2015). The alignment of these fossil valleys, however, may also bear a tectonic control (Kothyari and Juyal, 2013). Dhauliganga valley in the Garhwal Himalaya also experienced aggradation upto $\sim 12 \mathrm{ka}$ and formation of landslide dammed lake (Srivastava et al., 2013b). This lake sequence archived record of climate variation and its correspondence with solar variability from $12-7 \mathrm{ka}$. Alluviation and incision history of Yamuna river between MBT and HFT using geomorphology, sedimentology and OSL chronology of terraces indicated two phases of aggradation at $>37-24 \mathrm{ka}$ and $15-11 \mathrm{ka}$ in the late Pleistocene and three, at 7-4 ka; 3-2 ka and at <2 ka, in the Holocene. The period of incision and terrace formation is suggested to be influenced by strengthenedISM (Dutta et al., 2012). The Dun valley, NW Himalaya experienced aggradation from $>40$ ka until early Holocene (Pandey et al., 2014). Temporal comparison of sediment storage in dun and records of aggradation and incision in the downstream in the Ganga shows that (i) aggradation in the dun valley and in the hinterland are coeval (ii) phases of incision in dun generally overlaps with aggradation in the downstream regions in Ganga basin (Densmore et al., 2015).

The sediment characteristics and geomorphology of such fill terraces, described from Higher Himalaya along the Alaknanda River highlighted that the role oflocal surface processes may be dominant in valley aggradation (Devrani and Singh, 2014). Lithium ( $\mathrm{Li}$ ) isotopic composition of clays from these sedimentary fills, in the Alaknanda river valley, however, suggested a tight linkages between climate and chemical weathering. Between 25-10 ka, weathering rates in Garhwal Himalaya decreased despite of intensified monsoon. This indicated that,on such timescales, runoff and physical erosion at the catchment scale overwhelms and the moisture availability and temperature play a subsidiary role on chemical weathering (Dosetto et al., 2015).

The expressions of neotectonic activity in the Himalaya helps in understanding the evolutionary models of this mountain chain. Relict lake sediments in Gori Ganga, Dhauli Ganga and Kali Ganga provided evidences of neotectonic activity along the STDS, in form of soft sediment deformation (seismites). A study describing evidences from geomorphology, seismites and modern seismicity in Kashmir valley, NW Himalaya suggested activity along central Kashmir fault (CKF) and that pull-apart tectonics being 
responsible for the formation of the valley during the Quaternary (Alam et al., 2015). The seismites bearing horizon and the activity was constrained between 17$11 \mathrm{ka}$ (Rana et al., 2013).Similar evidences of 26-25 ka old seismicity are also provided from the fluviolacustrine deposits at the Yamuna River exit (Pandey and Pandey, 2015).

During the last five years, to ascertain the deformation and its structural style, studies focused on analysing the landscape using the tectonic geomorphic indices in conjunction with spatial distribution of landslides, terraces and drainage anomalies e.g.Kumaun Lesser Himalaya (Agarwal et al., 2012; Asthana et al., 2015). Himalayan front is marked by growth of anticlines and the quantitative geomorphology on these anticlines demonstrate interrelationship among faulting, anticline growth and surface processes (Barnes et al., 2011). Geomorphic studies on longitudinal river profiles, morphometry and on the Mohand and Chandigarh anticlines indicated (i) most growth in catchment size and relief took place within $\sim 5 \mathrm{~km}$ of the fault tip (ii) relief and erosion of the two flanks of anticline is dependent on the base level and uplift rates (Barnes et al., 2011). Kangra re-entrant, NW sub-Himalaya, from north-south, has JT (Jwalamukhi Thrust), ST (Soan thrust) and HFT as major tectonic discontinuities. Using chronologically constrained strath terraces in the area, a study quantified the deformation and crustal shortening rates over the period of last $40 \mathrm{ka}$ and indicated that a back thrust of Janauri----anticline is also accommodating the shortening in the area. The total shortening estimated was $\sim 14 \mathrm{~mm} / \mathrm{a}$ that roughly equals GPS derived modern rates. (Thakur et al., 2014). Another similar study in the NW Himalayan front suggested that the two frontal thrusts namely, Medlicott-Wadia Thrust and Main Frontal Thrust, absorb a shortening rate of 13.2 and $27.2 \mathrm{~mm} / \mathrm{yr}$ respectively over the Late Pleistocene time scales (Vassallo et al., 2015). Convergence rates along the Garhwal mountain front, computed using dated terrace are $10.8 \pm 2.2 \mathrm{~mm} / \mathrm{yr}$ (Parkash et al., 2011). A study using data on 44 drainage basins from the KumaunHimalaya suggestedthatthe Lesser Himalayan blockshows a regional scale block tilting in SE to NW directions and the Siwalik block in NE-SE direction (Goswami and Deopa, 2013).Offsetting in Quaternary sediments in and around Betalghat, Kumaun area suggested a reactivation of NNE-SSW trending oblique transverse normal fault (Mehta and Sanwal, 2011).Luirei et al (2014) provided geomorphic evidences of extensional tectonics at $\sim 17 \mathrm{ka}$, alongthe MBT in Kumaun Himalaya. Channel migration, in Dabka and Baur rivers in Kumaunfrontal Himalaya, occurred in response to the activity along the HFT that took place between 500-100 ka (Luirei et al., 2015). Basin asymmetry parameters in the parts of Kali River, Kumaun Himalaya also indicated SE and NW directed ground tilting across the North Almora Thrust (NAT) that suggested an oblique slip type movement along the trust (Agarwal and Sharma, 2011). Sedimentary archives from the alluvial fans at mountain front of the Kumaun Himalaya showed gravel facies in the basal event extending to the distal fan while that in the upper extended only to mid fan region indicating tectonically controlled changes in the gradient of the river during the past (Goswami and Mishra, 2013).

\section{Arunachal Himalaya}

In the NE Lesser Himalaya (Arunachal Himalaya), using drainage morphometric parameter, occurrence of seismites and bedrock geology a fault, parallel to strike of Himalaya, is identified and termed as Kamala River Fault, (Bhakuni et al., 2012; 2013). Similarly, based on occurrence of uplifted terraces and morphometric indices, a neotectonically active outof-sequence thrust and deformation frontal belt of NE Arunachal Himalaya, at the extit of Burai River and between Siang and Dibang rivers, is recognized (Devi et al., 2011; Luirei et al., 2012). In higher NE Himalaya, at Tuting, along the Siang River Srivastava and Misra (2012) tested luminescence dating protocols on uplifted terraces and suggested that ages derived using Infrared Stimulated Luminescence on feldspars, at an elevated temperatures of $225^{\circ} \mathrm{C}$ provides an overestimated ages. The OSL chronology on quartz fromSiang River sediments indicated three episodes of bedrock incision between >21-8 ka. In schuppen belt of Nagaland, NE India, a study involving observations on strath terraces, shutter ridges and river morphology indicated neotectonic activity and deformation in Medziphema intermontane basin(Aier et al., 2011). 


\section{Conclusions}

During the last five years the Indian contribution focused on the understanding (i) the extreme events, their geomorphic responses and on developing predictive model of related geomorphic damages. (ii) River responses to continuing deformation in Himalaya during the late Pleistocene. Efforts are made to estimate convergence and crustal shortening rates in different tectonic settings like re-entrants, Syntaxial zones etc. A newer approach involving drainage style and morphometry is being utilized to understand the growth of frontal anticlines. Sedimentology,

\section{References}

Agarwal K K and Sharma V K (2011) Quaternary tilt-block tectonics in parts of Eastern Kumaun Himalaya, India Zeitschriftfür Geomorphologie 55 197-208

Agarwal K K, Prakash C, Ali S N and Jahan N (2012) Morphometric analysis of the Ladhiya and Lohawati river basins, Kumaun Lesser Himalaya, India Zeitschriftfür Geomorphologie 56 201-224

Aier I, Luirei K, Bhakuni S S, Thong G T, Kothyari G C (2011) Geomorphic evolution of Medziphemaintermontane basin and Quaternary deformation in the schuppen belt, Nagaland, NE India Zeitschriftfür Geomorphologie $55247-$ 265

Alam A, Ahmad S, Bhat M S and Ahmad B (2015) Tectonic evolution of Kashmir basin in northwest Himalayas Geomorphology 239 114-126

Asthana A K L, Gupta A K, Luirei K, Bartarya S K, Rai S K and Tiwari S K (2015) A Quantitative Analysis of the Ramganga Drainage basin and structural control on drainage pattern in the fault zones, Uttarakhand Jour Geol Soc India 86 9-22

Bali R, Agarwal K K, Ali S N, Rastogi S K and Krishna K (2012) Drainage morphometry of Himalayan Glacio-fluvial basin, India: hydrologic and neotectonic implications Environmental Earth Sciences 66 1163-1174

Barnes J B, Densmore A L, Mukul M, Sinha R, Jain V and Tandon S K (2011) Interplay between faulting and base level in the development of Himalayan frontal fold topography Jourl Geophysical Research: Earth Surface 116 1-19.doi:10.1029/2010JF001841

Bhakuni S S, Luirei K, Devi R K M (2012) Soft-sediment deformation in the Middle Siwalik rocks of Arunachal geomorphology of terraces, tectonic geomorphic indices and luminescence chronology are frequently used tools.

\section{Acknowledgement}

PS, YR and BP acknowledge Directors of Wadia Institute of Himalayan Geology and National Centre for Antarctic and Ocean Research, Birbal Sahni Institute of Paleobotany for encouragement. YPS acknowledge Head, Department Geology, HNB Garhwal University, Srinagar.

Pradesh, NE Himalaya Himalayan Geology 33 139-145

Bhakuni S S, Luirei K and Kothyari G C (2013) Neotectonic Fault in the middle part of Lesser Himalaya, Arunachal Himalaya: a study based on structural and morphotectonic analyses Himalayan Geology 34 57-64Bhatt C M, Rao G S, Manjusree P and Bhanumurthy V (2011) Potential of high resolution satellite data for disaster management: a case study of Leh, Jammu \& Kashmir (India) flash floods, 2010 Geomatics Natural Hazards and Risk 2 365-375

Bookhagen B and Burbank D W (2010) Toward a complete Himalayan hydrological budget: Spatiotemporal distribution of snowmelt and rainfall and their impact on river discharge Jour Geophysical Research 115 1-25

Brookfield M E and Andrews-Speed C P (1984) Sedimentology, petrography and tectonic significance of the shelf, flysch and molasse clastic deposits across the Indus Suture Zone, Ladakh, NW India Sedimentary Geology 40 249-286

Chaudhary S, Shukla U K, Sundriyal Y P, Srivastava P and Jalal $\mathrm{P}(2015)$ Formation of paleovalleys in the Central Himalaya during valley aggradation Quaternary International 371 254-267

Densmore A L, Sinha R, Sinha S, Tandon S K and Jain V (2015) Sediment storage and release from Himalayan piggyback basins and implications for downstream river morphology and evolution Basin Research doi:10.1111/bre.12116

Devi R M, Bhakuni S S and Bora P K (2011) Neotectonic study along mountain front of northeast Himalaya, Arunachal Pradesh, India Environmental Earth Sciences 63 751-762

Devrani R, Singh V, Mudd S M andSinclair H D (2015) Prediction of flash flood hazard impact from Himalayan river profiles Geophysical Research Letters 42 5888-5894

Devrani R and Singh V (2014) Evolution of valley-fill terraces in the Alaknanda Valley, NW Himalaya: Its implication on 
river response studies Geomorphology 227 112-122

Devrani R and Singh V (2013) Determining the geomorphic changes in Srinagar (Garhwal) valley, NW Himalaya in last two centuries using landscape painting Zeitschriftfür Geomorphologie 58163-173

Dobhal D P, Gupta A K, Mehta M and Khandelwal D D (2013) Kedarnath disaster: facts and plausible causes Current Science 105 171-174

Dosseto A, Vigier N, Joannes-Boyau R C, Moffat I, Singh T and Srivastava P (2015) Rapid response of silicate weathering rates to climate change in the Himalaya Geochemical Perspective Letters 1 10-19 doi: 10.7185/geochemlet.1502

Dutta S, Suresh N and Kumar R (2012) Climatically controlled Late Quaternary terrace staircase development in the foldand-thrust belt of the Sub Himalaya Palaeogeography, Palaeoclimatology, Palaeoecology 356 16-26

Ghosh P, Sinha S and Misra A (2015) Morphometric properties of the trans-Himalayan river catchments: Clues towards a relative chronology of orogen-wide drainage integration Geomorphology 233 127-141

Gansser A (1964) Geology of the Himalayas. London/New York/ Sydney: Wiley Interscience p 289

Goswami P K and Deopa T (2013) Quaternary block-tilting in southern Himalayan ranges of eastern Uttarakhand, India Zeitschriftfür Geomorphologie 57 45-60

Goswami P K and Mishra J K (2013) Climatic and tectonic controls on the sedimentary processes of an alluvial fan of the western Ganga Plain, India Geological Magazine 150 240-253

Gupta V, Dobhal D P and Vaideswaran S C (2013) August 2012 cloudburst and subsequent flash flood in the Asi Ganga, a tributary of the Bhagirathi river, Garhwal Himalaya, India Current Science 105 249-253

Gaurav K, Sinha R and Panda P K (2011) The Indus flood of 2010 in Pakistan: A perspective analysis using remote sensing data Natural Hazards 59 1815-1826

Islam M A, Chattoraj S L and Ray C P (2014) Ukhimath landslide 2012 at Uttarakhand, India: Causes and consequences International Jour Geomatics and Geosciences 4544

Jade S, Mukul M, Bhattacharyya A K, Vijayan M S M, Jaganathan S, Kumar A, Tiwari R P, Kumar A, Kalita S, Sahu S C and Krishna A P (2007) Estimates of interseismic deformation in Northeast India from GPS measurements Earth and Planetary Science Letters 263 221-234

Juyal N, Sundriyal Y P, Rana N, Chaudhary S and Singhvi A K (2010) Late Quaternary fluvial aggradation and incision in the monsoon-dominated Alaknanda valley, Central
Himalaya, Uttrakhand, India Journal of Quaternary Science 25 1293-1304

Juyal N (2010) Cloud burst-triggered debris flows around Leh Current Science 99 1166-1167

Juyal N (2014) Ladakh: The High-Altitude Indian Cold Desert. In Landscapes and Landforms of India Springer Netherlands 115-124

Kotal S D, Roy S S and Roy Bhowmik S K (2014) Catastrophic heavy rainfall episode over Uttarakhand during 16-18 June 2013-observational aspects Current Science 107 234-245

Kothyari G C, Pant P D and Luirei K(2012) Wedge failure analysis of landslides occurring in the Main Boundary Thrust (MBT) zone: SoutheasternKumaun, Uttarakhand, India JourGeol Soc India 80 101-110

Luirei K, Bhakuni S S, Srivastava P and Suresh N (2012) Late Pleistocene - Holocene tectonic activities in the frontal part of NE Himalaya between Siang and Dibang valleys, Arunachal Pradesh, India Zeitschriftfür Geomorphologie 56 477-493

Luirei K, Bhakuni S S, Suresh N, Kothyari G C and Pant P D (2014) Tectonic geomorphology and morphometry of the frontal part of Kumaun Sub-Himalaya: Appraisal of tectonic activity Zeitschriftfür Geomorphologie 58 435458

Luirei K, Bhakuni S S and Kothyari G C (2015) Tectonic forcing of drainage and geomorphic units across the Himalayan Frontal Thrust, Kumaun Himalaya, India Geomorphology 239 58-72

Mehta J S and Sanwal R (2011) Evidence of active tectonics along oblique transverse normal fault in the Kosi River valley around Betalghat, Kumaun Lesser Himalaya, India Current Science $101541-543$

Nag D and Phartiyal B (2015) Climatic variations and geomorphology of the Indus River valley, between Nimo and Batalik, Ladakh (NW Trans Himalayas) during Late Quaternary Quaternary International 371 87-101

Pandey A K and Pandey P (2015) Soft sediment deformation structures in late Quaternary abandoned channel fill deposit of Yamuna river in NW Sub-Himalaya, India Current Science 108 1717-1725

Phartiyal B, Singh R and Kothyari G C (2015) Late-Quaternary geomorphic scenario due to changing depositional regimes in the Tangtse Valley, Trans-Himalaya, NW India Palaeogeography, Palaeoclimatology, Palaeoecology 422 11-24

Phartiyal B, Sharma A and Kothrari G C (2013) Damming of River Indus during Late Quaternary in Ladakh Region of Trans-Himalaya, NW India: Implica-tions to Lake 
formation-climate and tectonics Chin Sci Bull (Chin Ver) 58 142-155

Phartiyal B and Kothyari G C (2012) Impact of neotectonics on drainage network evolution reconstructed from morphometric indices: Case study from NW Indian Himalaya Zeitschriftfür Geomorphologie 56 121-140

Pathak V, Pant C C and Darmwal G S (2013) Geomorphological and seismological investigations in a part of western Kumaun Himalaya, Uttarakhand, India Geomorphology $19381-90$

Rana N, Singh S, Sundriyal Y P and Juyal N (2013) Recent and past floods in the Alaknanda valley: causes and consequences Current Science 105 1209-1212

Rana N, Bhattacharya F, Basavaiah N, Pant R K and Juyal N (2013) Soft sediment deformation structures and their implications for late quaternary seismicity on the south tibetan detachment system, central Himalaya (Uttarakhand), India Tectonophysics 592 165-174

Rana N, Sundriyal Y P and Juyal N (2012) Recent cloudburstinduced landslides around Okhimath, Uttarakhand Current Science 103 1389-1390

Ray Y and Srivastava P (2010) Widespread aggradation in the mountainous catchment of the Alaknanda Ganga River System: timescales and implications to interland foreland relationships Quaternary Science Reviews 29 2238-2260 DOI: 10.1016/j.quascirev.2010.05.023

Pandey A K, Pandey P, Singh G D and Juyal N (2014) Climate footprints in the Late Quaternary-Holocene landforms of Dun Valley, NW Himalaya, India Current Science 106245

Parkash B, Rathor R S, Pati P,Jakhmola R P and Singh S (2011) Convergence rates along the Himalayan frontal thrust inferred from terraces at Chandidevi Temple Hill, Hardwar, Northwestern Himalaya Current Science 100 1426-1432

Sati S P, Sundriyal Y P, Rana N and Dangwal S (2011) Recent landslides in Uttarakhand: Nature's fury or human folly Current Science 100 1617-1620

Sati S P and Gahalaut V K (2013) The fury of the floods in the north-west Himalayan region: The Kedarnath tragedy Jour Geomatics, Natural Hazards and Risk 4 193-201

Shukla D P, Dubey C S, Ningreichon A S, Singh R P, Mishra B K and Singh S K (2014) GIS-based morpho-tectonic studies of Alaknanda river basin: a precursor for hazard zonation Natural Hazards 71 1433-1452

Singh D S (2014) Surface processes during flash floods in the glaciated terrain of Kedarnath, Garhwal Himalaya and their role in the modification of landforms Current Science $\mathbf{1 0 6}$ 594
Singh V, Devrani R and Ansari Z (2012) Estimation of the rate of erosion of valley fill deposits in a part of the NW Lesser Himalaya Episodes 35445-452

Srivastava P, Kumar A, Mishra A, Meena N K, Tripathi J K, Sundriyal Y P and Gupta A K (2013) Early Holocene monsoonal fluctuations in the Garhwal higher Himalaya as inferred from multi-proxy data from the Malaripaleolake Quaternary Research 80 447-458

Srivastava P and Misra D K (2012) Optically stimulated luminescence chronology of terrace sediments of Siang River, Higher NE Himalaya: Comparison of Quartz and Feldspar chronometers Journal of the Geological Society of India 79 252-258

Srivastava P, Ray Y, Phartiyal B and Sharma A (2013) Late Pleistocene-Holocene morphosedimentary architecture, Spiti River, arid higher Himalaya Intern Jour Earth Sciences 102 1967-1984

Sundriyal Y P, Shukla A D, Rana N, Jayangondaperumal R, Srivastava P, Chamyal L S and Juyal N (2015) Terrain response to the extreme rainfall event of June 2013: Evidence from the Alaknanda and Mandakini River Valleys, Garhwal Himalaya, India Episodes 38 179-188

Sangode S J, Phadtare N R, Meshram D C, Rawat S and Suresh $\mathrm{N}(2011)$ A record of lake outburst in the Indus valley of Ladakh Himalaya, India Current Science 100 1712-1718

Sangode S J, Rawat S, Meshram D C, Phadtare N R and Suresh $\mathrm{N}(2013)$ Integrated mineral magnetic and lithologic studies to delineate dynamic modes of depositional conditions in the Leh valley basin, Ladakh Himalaya, India Jour Geological Society of India $\mathbf{8 2}$ 107-120

Sant D A, Wadhawan S K, Ganjoo R K, Basavaiah N, Sukumaran P and Bhattacharya S (2011a) Morphostratigraphy and palaeoclimate appraisal of the Leh valley, Ladakh Himalayas, India Jour Geological Society of India 77 499510

Sant D A, Wadhawan S K, Ganjoo R K, Basavaiah N, Sukumaran $P$ and Bhattacharya S (2011b) Linkage of paraglacial processes from last glacial to recent inferred from Spituk sequence, Leh valley, Ladakh Himalaya Jour Geological Society of India 78 147-156

Thakur V C, Joshi M, Sahoo D, Suresh N, Jayangondapermal R and Singh A (2014) Partitioning of convergence in Northwest Sub-Himalaya: estimation of late Quaternary uplift and convergence rates across the Kangrareentrant, North India Intern Jour Earth Sciences 103 1037-1056

Thayyen R J, Dimri A P, Kumar P and Agnihotri G (2013) Study of cloudburst and flash floods around Leh, India, during August 4-6, 2010 Natural Hazards 65 2175-2204 
Thiede R C, Bookhagen B, Arrowsmith J R, Sobel E R and Strecker M R (2004) Climatic control on rapid exhumation along the Southern Himalayan Front Earth and Planetary Science Letters 222 791-806

Valdiya K S (1980) Geology of Kumaun Lesser Himalaya Wadia Institute of Himalayan Geology

Vellore R K, Kaplan M L, Krishnan R, Lewis J M, Sabade S, Deshpande N, Singh B B, Madhura R K and Rao M R (2015) Monsoon-extratropical circulation interactions in Himalayan extreme rainfall Climate Dynamics DOI 10.1007/s00382-015-2784-x

Vassallo R, Mugnier J L, Vignon V, Malik M A, Jayangondaperumal R, Srivastava P, Jouanne F and Carcaillet J (2015) Distribution of the Late-Quaternary deformation in Northwestern Himalaya Earth and Planetary Science Letters 411 241-252
Verma N, Devrani R and Singh V (2014) Is Ganga the longest river in the Ganga Basin, India? Current Science 1072018 2022

Wasson R J, Sundriyal Y P, Chaudhary S, Jaiswal M K, Morthekai P, Sati S P and Juyal N (2013) A 1000-year history of large floods in the Upper Ganga catchment, central Himalaya, India Quaternary Science Reviews 77 156-166

Ziegler A D, Wasson R J, Bhardwaj A, Sundriyal Y P, Sati S P, Juyal N, Nautiyal V, Srivastava P, Gillen J and Saklani U (2014) Pilgrims, progress, and the political economy of disaster preparedness-The example of the 2013 Uttarakhand flood and Kedarnath disaster Hydrological Processes 28 5985-5990. 